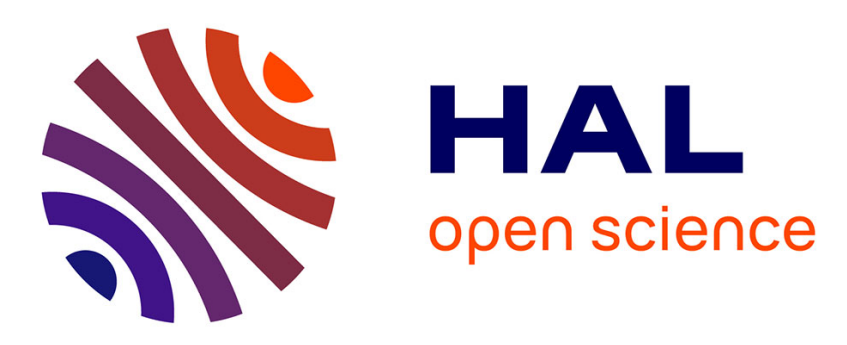

\title{
Influence of tree species on carbon and nitrogen transformation patterns in forest floor profiles
}

Trum, Titeux, Ranger, Delvaux

\section{To cite this version:}

Trum, Titeux, Ranger, Delvaux. Influence of tree species on carbon and nitrogen transformation patterns in forest floor profiles. Annals of Forest Science, 2011, 68 (4), pp.837-847. 10.1007/s13595011-0080-4 . hal-00930813

\section{HAL Id: hal-00930813 https://hal.science/hal-00930813}

Submitted on 1 Jan 2011

HAL is a multi-disciplinary open access archive for the deposit and dissemination of scientific research documents, whether they are published or not. The documents may come from teaching and research institutions in France or abroad, or from public or private research centers.
L'archive ouverte pluridisciplinaire HAL, est destinée au dépôt et à la diffusion de documents scientifiques de niveau recherche, publiés ou non, émanant des établissements d'enseignement et de recherche français ou étrangers, des laboratoires publics ou privés.

$$
\text { Copyright }
$$




\title{
Influence of tree species on carbon and nitrogen transformation patterns in forest floor profiles
}

\author{
Florence Trum • Hugues Titeux • Jacques Ranger • \\ Bruno Delvaux
}

Received: 30 April 2010 / Accepted: 2 December 2010 /Published online: 10 June 2011

(C) INRA and Springer Science+Business Media B.V. 2011

\begin{abstract}
- Background Among forest management practices, forest tree species substitution influences biogeochemical cycles and soil interactions rapidly (decades) and significantly.

- Methods We studied the impact of tree species on forest floor properties in 27-year-old monospecific stands of oak, beech, spruce and Douglas-fir, grown in common garden.

- Results In spite of similar litterfall C-inputs (1.3-1.8 Mg $\left.\mathrm{ha}^{-1} \mathrm{yr}^{-1}\right), \mathrm{C}$-stocks strongly differed between coniferous (16-21 $\mathrm{Mg} \mathrm{ha}^{-1}$ ) and broadleaved (7-9 $\mathrm{Mg} \mathrm{ha}^{-1}$ ) forest floors. The large C-mineralization under oak (196 C- $\mu \mathrm{g}$ $\left.\mathrm{C}_{\text {total }}-\mathrm{g}^{-1} \mathrm{~d}^{-1}\right)$ relatively to other stands $(125-147 \mathrm{C}-\mu \mathrm{g}$ $\mathrm{C}_{\text {total }} \mathrm{g}^{-1} \mathrm{~d}^{-1}$ ) and the large dissolved organic carbon release under broadleaved forest floors may explain this difference. Spruce forest floor exhibited the lowest net nitrification and the largest contribution of organic anions to the anionic charge of aqueous leachate (62.5\% $\% 1.7)$. Conversely, Douglas-fir forest floor exhibited the largest relative nitrification and the largest contribution of nitrate to the anionic charge $(70.8 \% \pm 0.7)$.

- Conclusion We conclude that tree species induce a specific signature in term of proton donors at the forest floor level (organic vs nitric acid), which involves potential impacts on pedogenetic processes in the mineral horizon beneath.
\end{abstract}

\section{Handling Editor: Erwin Dreyer}

F. Trum $(\bowtie) \cdot$ H. Titeux $\cdot$ B. Delvaux

Earth and Life Institute, Environmental Science,

Université catholique de Louvain,

Croix du Sud 2/10,

1348 Louvain-la-Neuve, Belgium

e-mail: Florence.Trum@uclouvain.be

J. Ranger

Biogéochimie des écosystèmes forestiers, INRA, Centre de Nancy,

54280 Champenoux, France
Keywords DOC and $\mathrm{CO}_{2}$ release · Forest floor horizons · $\mathrm{N}$-release $\cdot$ Common garden $\cdot$ Tree species

\section{Introduction}

The influence of forest tree species on biogeochemical cycles and soil interactions has for a long time attracted numerous scientists, and has been covered by an intensive literature. The interest in this research topic originates from the substitution issue of natural vegetation by monospecific coniferous stands as a cause of soil acidification (Binkley and Giardina 1998). More recently, with the Kyoto protocol, the interest has been rather focused on tree species potential for mitigation of greenhouse gases and for carbon sequestration (Jandl et al. 2007).

Soil acidification and carbon sequestration are influenced by forest floor decomposition, through the release of organic/inorganic acids and dissolved organic carbon (DOC) (Guggenberger and Kaiser 1998). The impact of forest tree species on forest floor properties has been largely studied particularly in common garden. This experimental design makes it possible to minimize confounding effects such as local climate, geology, soil type, forest stand age, or past land use management (Binkley and Giardina 1998; Meentemeyer 1978) by simultaneous plantations of different tree species in homogeneous pedo-climatic conditions (Gower and Son 1992; Vesterdal et al. 2008). Previous studies in common garden highlighted the following points: (i) tree species can modify topsoil $\mathrm{N}$-mineralization rates in a short time (decades) (Gower and Son 1992), (ii) forest floors exhibit differences in $\mathrm{C} /$ nutrient ratios, $\mathrm{pH}$ and nutrient contents according to the tree species (Vesterdal and Raulund-Rasmussen 1998), (iii) tree species influence microbial and faunal populations through variation in litter 
lignin and $\mathrm{Ca}$ concentration (Hobbie et al. 2006), (iv) the influence of tree species on $\mathrm{C}$ and $\mathrm{N}$ concentration and $\mathrm{C} / \mathrm{N}$ ratio is more pronounced in the forest floor than in the litterfall and the topsoil because of large differences of turnover rates (Vesterdal et al. 2008), and (v) Hansen et al. (2009) conclude that tree species do not influence the amount of litterfall while site-related factors do, and that a large variability in forest floor accumulation could primarily be due to a difference in litter decomposition.

However, the impact of forest tree species on the release of soluble compounds by the forest floor has not yet been explored particularly for the Douglas-fir, despite the crucial involvement of these compounds in pedogenetic processes. Moreover, the forest floor is not a black box. Forest floor has a heterogeneous composition and can be divided into different layers (horizons) corresponding to successive stages of decomposition (Wardle 1993). Given that previous studies concluded that the main difference between tree species is decomposition rate (Hansen et al. 2009; Vesterdal et al. 2008), studying forest floor profiles should provide a clearer picture of the tree species decomposition process.

The experimental site of Breuil-Chenue in the Morvan mountains (France) is a common garden set up in 1976 specifically to compare biogeochemical cycles between tree species. On this site, no studies have particularly yet considered the forest floor compartment. Nevertheless, Moukoumi et al. (2006) have already studied organic matter biodegradability and mineral nutrient availability in the topsoil, while Zeller et al. (2007) have considered Ntransformations in the litterfall and the topsoil.

In this paper, our specific objective is to characterize the release of dissolved products $\left(\mathrm{NH}_{4}^{+}, \mathrm{NO}_{3}^{-}, \mathrm{DON}, \mathrm{DOC}\right.$, cations and anions) in forest floor profiles of four trees widespread in Europe: Douglas-fir (Pseudotsuga menziesii Franco), Norway spruce (Picea abies Karst), European beech (Fagus sylvatica L.) and oak Quercus petraea (Matt.) Liebl. To support our understanding, we provide a detailed characterisation of the forest floor layers (composition, C-and $\mathrm{N}$-transformation). To achieve this, forest floor horizon samples were collected in the site of Breuil, individually incubated in vitro for determination of $\mathrm{C}$ - and $\mathrm{N}$ mineralization and leached for measuring the release of soluble compounds.

\section{Materials and methods}

\subsection{Experimental site}

The study was carried out on forest floors sampled in the experimental site of Breuil-Chenue set up by the Institut National de la Recherche Agronomique (INRA) in the Natural Park of the Morvan, France (47 $18^{\prime} 10^{\prime \prime}$ N; $\left.4^{\circ} 4{ }^{\prime} 44^{\prime \prime} \mathrm{E}\right)$. The site contains two adjacent blocks with replicated stands. It is established on a plateau at $650 \mathrm{~m}$. Climate is submountain Atlantic, with $1400 \mathrm{~mm}$ mean annual rainfall and $6^{\circ} \mathrm{C}$ mean annual temperature. The native forest was a 150-year-old coppice composed mainly of beech (Fagus sylvatica L.) and oak Quercus petraea (Matt.) Liebl. In 1976, this initial forest was partially clear-felled (one stand was conserved in each block) and replaced by mono-specific 0.1 ha stands of different species (one plot by block) (Bonneau et al. 1977). Previous studies showed that the site heterogeneity was minor (Bonneau et al. 1977; Ranger et al. 2004). Out of the plantations of block 1, we selected the four tree species studied here.

The soil is an acid brown soil, and classified as an Alocrisol (AFES 1998) or an alumnic Cambisol (IUSS 2006). It developed from a granite which was very poor in cation-bearing minerals $(0.5 \% \mathrm{MgO} ; 0.6 \% \mathrm{CaO} ; 4.4 \%$ $\mathrm{K}_{2} \mathrm{O}$ ). The soil is strongly acid, $\mathrm{pH}$ is 3.8 in surface horizons and increases with depth (4.7-4.8). Soil texture is sandy-loamy throughout the whole profile, with $40-55 \%$ sand and $15-20 \%$ clay. Carbon concentrations decrease from $0.44 \mathrm{~g} \mathrm{~kg}^{-1}$ in surface horizons to $0.04 \mathrm{~g} \mathrm{~kg}^{-1}$ in deeper horizons (Bonneau et al. 1977).

\subsection{Litterfall and forest floor sampling}

Five litter-traps $\left(0.5 \mathrm{~m}^{2}\right)$ were placed in each stand to collect litterfall continuously. Sampling occurred every 3 months for 3 years between September 2002 and September 2005. Each sample was sorted and dried. All samples of leaf/needle litterfall were considered in order to assess the average annual $\mathrm{C}$-input by litterfall and its variability. For each forest stand, composite samples were analysed for $\mathrm{C}$, N, phosphorus (P), lignin, cellulose and cations concentrations. The composite samples were constituted with leaf/needle litterfall samples from all periods, applying weighting factors according to the dry weight of corresponding litterfall sample.

In each forest stand, we sampled forest floor horizons in December 2003 after leaf fall. We sampled separately Oln (plant remains), Olv (poorly fragmented), Of (fragmented) sub-horizons according to the definitions of Brêthes et al. (1995). The material was collected quantitatively on $1 \mathrm{~m}^{2}$ surface representing forest floor morphology in the plot. An Oh horizon (dark humified organic matter) was collected under spruce, whereas transitional horizons were collected in other stands: OfOh under oak and Douglas-fir and Of-Ah under beech. The symbol $\mathrm{O}^{*}$ is used in the following text to identify the deepest horizon of the forest floor, which is either Oh or Of-Oh or Of-Ah. 


\subsection{Analysis of litterfall and forest floor horizons}

Carbon and $\mathrm{N}$ concentrations were measured by gas chromatography after dry combustion $\left(1800^{\circ} \mathrm{C}\right)$ with a Thermo Quest CHN autoanalyzer. We measured the concentration of lignin and cellulose in litterfall by aciddetergent extraction (Van Soest 1963). Elemental analyses $(\mathrm{Ca}, \mathrm{Mg}, \mathrm{K}, \mathrm{Na}, \mathrm{Mn}, \mathrm{Al}$ and $\mathrm{Fe}$ ) were carried out by calcination $\left(450^{\circ} \mathrm{C}\right)$ and digestion with $\mathrm{HNO}_{3}, \mathrm{HF}$ and $\mathrm{HClO}_{4}$, and measured by induced plasma coupled atomic emission spectroscopy (ICP-AES, Jarell Ash). Horizon thicknesses were estimated in the field. Root colonization expressed by the volume percentage taken up by roots in each horizon was visually estimated both in the field and during the sample sorting.

\subsection{Incubation, leaching and chemical analysis of leachates}

Forest floor materials dedicated to incubation were neither dried nor rewetted before the constitution of columns. Incubation was carried out in PVC-columns with perforated bottom covered by polyamide net $(50-\mu \mathrm{m}$ mesh size). Each column $($ diameter $=115 \mathrm{~mm}$, height $=200 \mathrm{~mm})$ contained $15 \mathrm{~g}$ (equivalent dry weight) of one horizon. All the columns were covered, but not hermetically closed, and pre-incubated during 6 weeks at $4^{\circ} \mathrm{C}$. At the end of the preincubation period, each column was leached with MilliQ water $(150 \mathrm{ml})$.

We introduced two plastic cups into each column: one with $1 \mathrm{M} \mathrm{NaOH}$ for $\mathrm{CO}_{2}$ measurement and one with water to balance $\mathrm{NaOH}$-related dehydration. The columns were then closed hermetically. Initial $\mathrm{CO}_{2}$ content was measured in a closed column without sample (blank column). Columns of separated horizon were incubated in triplicate for 32 days at $4^{\circ} \mathrm{C}$. At the end of the incubation period, columns were leached again with MilliQ water $(150 \mathrm{ml}$, with a 1:10 ratio between organic material and water quantity). The leachates were filtered through $0.45-\mu \mathrm{m}$ pore size Gellman filter and analysed.

We measured $\mathrm{pH}$ with CG804 pH-meter, ammonium $\left(\mathrm{NH}_{4}{ }^{+}\right)$concentration by FIA (Alpkem FS3000), cation concentrations $\left(\mathrm{Na}^{+}, \mathrm{K}^{+}, \mathrm{Ca}^{2+}, \mathrm{Mg}^{2+}, \mathrm{Al}^{3+}, \mathrm{Fe}^{2+}, \mathrm{Mn}^{2+}\right.$, $\left.\mathrm{Cu}^{2+}, \mathrm{Pb}^{2+}, \mathrm{Zn}^{2+}\right)$ by ICP-AES, and inorganic anion concentrations $\left(\mathrm{F}^{-}, \mathrm{Cl}^{-}, \mathrm{NO}_{3}{ }^{-}, \mathrm{NO}_{2}{ }^{-}, \mathrm{PO}_{4}{ }^{3-}, \mathrm{SO}_{4}{ }^{2-}\right)$ by ionic chromatography (HPLC, Dionex LC20 with IONPAC AS 11 column). The anionic deficit charge (ACD) was calculated by the difference between the sum of cationic charge and the sum of anionic charge. The concentrations of dissolved organic carbon (DOC) and total dissolved nitrogen (TDN) were measured with a total organic carbon analyser (SHIMADZU TV-V $\mathrm{V}_{\mathrm{CSH}-\mathrm{CSN}}$ ). The concentration of dissolved organic nitrogen (DON) was calculated by the difference between TDN and dissolved inorganic nitrogen (DIN), which was defined by the sum of $\mathrm{NH}_{4}{ }^{+}, \mathrm{NO}_{2}{ }^{-}$and $\mathrm{NO}_{3}{ }^{-}$concentrations. The release of

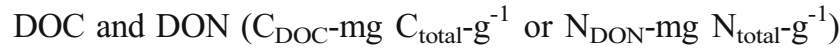
was defined by the ratio between the amount of DOC or DON in the leachate after incubation, and the initial amount of $\mathrm{C}$ or $\mathrm{N}$ in the corresponding sample.

\subsection{C- and N-mineralization}

The production of $\mathrm{CO}_{2}$ was measured every 10 or 11 days by back titration of $\mathrm{NaOH}$ with $\mathrm{HCl} 1 \mathrm{M}$ and deduction of the values from blank columns. C-mineralization was defined by the ratio between the average daily $\mathrm{CO}_{2}$ production and the initial amount of $\mathrm{C}$ in the corresponding sample.

Inorganic $\mathrm{N}\left(\mathrm{N}-\mu \mathrm{g} \mathrm{N}_{\text {total }^{-}} \mathrm{g}^{-1} \mathrm{~d}^{-1}\right)$ was extracted from $2.5 \mathrm{~g}$ (equivalent dry weight) sub-sample from column by using $\mathrm{KCl} 1 \mathrm{M}(2.5 \mathrm{~g}: 100 \mathrm{ml})$, before and after incubation. $\mathrm{NO}_{3}{ }^{-}$and $\mathrm{NH}_{4}{ }^{+}$concentrations in $\mathrm{KCl}$ extracts were measured by HPLC (Dionex LC20 with IONPAC AS 11 column) and flow injection analysis (FIA, Alpkem FS3000) respectively.

Net nitrification (N- $\mu \mathrm{g} \mathrm{N}_{\text {total- }} \mathrm{g}^{-1} \mathrm{~d}^{-1}$ ) was defined by the ratio between (1) net $\mathrm{NO}_{3}^{-}$production, which is the difference between final and initial $\mathrm{NO}_{3}{ }^{-}$concentrations in the $\mathrm{KCl}$ extracts, and (2) initial amount of $\mathrm{N}$ in the sample. Relative nitrification (\%) is defined by the ratio between (1) final $\mathrm{NO}_{3}{ }^{-}$in the $\mathrm{KCl}$ and water extracts, and (2) final mineral $\mathrm{N}\left(\mathrm{NH}_{4}{ }^{+}\right.$and $\left.\mathrm{NO}_{3}{ }^{-}\right)$in the $\mathrm{KCl}$ and water extracts. It is an alternative measure of nitrification considering $\mathrm{NO}_{3}{ }^{-}$production in relation to $\mathrm{NH}_{4}{ }^{+}$-supplying capacity (Robertson 1982).

DOC and DON releases, C-mineralization and net nitrification are all defined in function of the initial amount of $\mathrm{C}$ or $\mathrm{N}$ in the corresponding sample. Using these units facilitates comparison between species, since organic matter has a different composition between species and horizons.

\subsection{Statistical analysis}

The differences between means were compared with oneway analysis of variance (ANOVA1) and Fisher's least significant difference (LSD) test, with a significant level of 0.05 . All statistical analyses were performed with the SAS software (SAS Institute 1999). We compared the means between the four tree species, for $\mathrm{C}$ - and $\mathrm{N}$-mineralization and for the release of DOC, DON, $\mathrm{NH}_{4}{ }^{+}$and $\mathrm{NO}_{3}{ }^{-}$in each horizon. Furthermore, we compared in each forest floor the means of all sub-horizons weighted by their dry mass for Cand $\mathrm{N}$-mineralization and for the release of DOC, DON, $\mathrm{NH}_{4}^{+}$and $\mathrm{NO}_{3}^{-}$. We also performed some correlation analysis between litterfall and forest floor characteristics and C-mineralization using the SAS software. 


\section{Results}

\subsection{Forest floor morphology}

The forest floor, which encompasses Ol, Of and Oh horizons, was thicker under spruce $(40 \mathrm{~mm})$ than under the other tree species (Douglas-fir, $25 \mathrm{~mm}$; beech, $20 \mathrm{~mm}$; oak, $15 \mathrm{~mm})$. The Oh horizon was thick in the spruce forest floor $(10-20 \mathrm{~mm})$, while it was thin $(<2 \mathrm{~mm})$ and discontinuous in Douglas-fir and oak forest floors. Oh was absent under beech, and we observed mineral particles from Ah horizon in the lower part of Of horizon.

Tree roots colonized $\mathrm{Of}$ and $\mathrm{Oh}$ horizons whatever the forest floor, but mainly under spruce and beech. They were particularly abundant in the Oh horizon of spruce forest floor, where they represented about $25-30 \%$ of the horizon volume. In the other forest floors, we only observed fine roots (1-4 mm) which represented less than $5 \%$ of the volume. Root tips were covered by visible ectomycorrhizal fungi except under Douglas-fir forest floor. The presence of white fungal mats was visually detected in the four forest floors, mainly in Olv.

\subsection{Composition of litterfall}

The composition of litterfall composite samples is presented in Table 1. C-concentrations in litterfall were in the same range of values (47-48\%) under the four species. Nconcentrations significantly differed between tree species, and were in the order: spruce $<$ oak $<$ beech $<$ Douglas-fir $(P<0.0001)$. P-concentration was the lowest in oak litterfall and the highest in Douglas-fir litterfall $(P<0.0001)$. C:N ratios in litterfall significantly differed between tree species, and were in the order: Douglas-fir $<$ beech $<$ oak $<$ spruce $(P<0.0001)$. C:P ratio was the lowest in Douglas-fir litterfall and the highest in oak litterfall $(P<0.0001)$. Lignin concentrations in litterfall were similar under oak, spruce and Douglas-fir (31-34\%) but much higher under beech (54\%,P=0.0069). The concentrations of $\mathrm{Ca}, \mathrm{Mg}$ and $\mathrm{Mn}$ were the highest in Douglas-fir and oak litterfalls and the lowest in spruce litterfall. Beech litterfall exhibited the highest concentrations of $\mathrm{K} \quad(P<0.0001)$ and $\mathrm{Na}$ $(P<0.0001)$. Douglas-fir litterfall exhibited the highest concentrations of $\mathrm{Al}(P<0.0001)$ and $\mathrm{Fe}(P=0.0421)$.

\subsection{Composition of forest floor horizons}

The elemental composition of forest floor horizons is presented in Table 2. Whatever the tree species, Cconcentration, $\mathrm{C}: \mathrm{N}$ and $\mathrm{C}: \mathrm{P}$ ratio decreased with the horizons, $\mathrm{N}$ - and P-concentration reached a maximum in Of horizon. The values of $\mathrm{C}: \mathrm{N}$ ratio in $\mathrm{Ol}$ horizons were higher under oak and spruce than under other species. The lowest value of $\mathrm{C}: \mathrm{P}$ ratio was observed under beech whatever the forest floor horizon. Whatever the tree species, K, Na, $\mathrm{Al}$ and $\mathrm{Fe}$ concentrations exhibited the same pattern of increase with the horizons. For $\mathrm{Mg}$ and $\mathrm{Mn}$

Table 1 Composition of the tree species litterfalls. Means with different associated letters are significantly different from one another at the $P<0.05$ level according to the Fisher's least significant difference test $(n=3)$

\begin{tabular}{|c|c|c|c|c|c|c|c|c|c|c|c|c|c|c|}
\hline & $\begin{array}{l}\mathrm{C} \\
\%\end{array}$ & $\begin{array}{l}\mathrm{N} \\
\%\end{array}$ & $\begin{array}{l}\mathrm{P} \\
\% 0\end{array}$ & $\begin{array}{l}\mathrm{C}: \mathrm{N} \\
\text { atomic } \\
\text { ratio }\end{array}$ & $\begin{array}{l}\mathrm{C}: \mathrm{P} \\
\text { atomic } \\
\text { ratio }\end{array}$ & $\begin{array}{l}\text { Lignin } \\
\%\end{array}$ & $\begin{array}{l}\text { Cellulose } \\
\%\end{array}$ & $\begin{array}{l}\mathrm{Ca} \\
\mathrm{g} \mathrm{kg}^{-1}\end{array}$ & $\begin{array}{l}\mathrm{Mg} \\
\mathrm{g} \mathrm{kg}^{-1}\end{array}$ & $\begin{array}{l}\mathrm{K} \\
\mathrm{g} \mathrm{kg}^{-1}\end{array}$ & $\begin{array}{l}\mathrm{Na} \\
\mathrm{g} \mathrm{kg}^{-1}\end{array}$ & $\begin{array}{l}\mathrm{Mn} \\
\mathrm{g} \mathrm{kg}^{-1}\end{array}$ & $\begin{array}{l}\mathrm{Al} \\
\mathrm{g} \mathrm{kg}^{-1}\end{array}$ & $\begin{array}{l}\mathrm{Fe} \\
\mathrm{g} \mathrm{kg}^{-1}\end{array}$ \\
\hline \multicolumn{15}{|l|}{ Oak } \\
\hline Mean & 47 & 1.13 & 0.45 & 48 & 2684 & 34 & 26 & 4.0 & 0.93 & 2.3 & 0.08 & 2.3 & 0.13 & 0.11 \\
\hline \multirow[t]{2}{*}{ SD } & 1 & 0.02 & 0.01 & 1 & 63 & 3 & 1 & 0.2 & 0.05 & 0.1 & 0.00 & 0.1 & 0.01 & 0.01 \\
\hline & $\mathrm{a}$ & $\mathrm{c}$ & $\mathrm{c}$ & $\mathrm{b}$ & $\mathrm{a}$ & $\mathrm{b}$ & $\mathrm{a}$ & $\mathrm{b}$ & $\mathrm{a}$ & $\mathrm{c}$ & $\mathrm{c}$ & $\mathrm{b}$ & $\mathrm{c}$ & $\mathrm{b}$ \\
\hline \multicolumn{15}{|l|}{ Beech } \\
\hline Mean & 47 & 1.33 & 0.58 & 42 & 2095 & 54 & 21 & 3.2 & 0.58 & 3.5 & 0.15 & 2.0 & 0.16 & 0.11 \\
\hline \multirow[t]{2}{*}{ SD } & 1 & 0.01 & 0.01 & 1 & 4 & 8 & 6 & 0.1 & 0.1 & 0.1 & 0.01 & 0.1 & 0.02 & 0.01 \\
\hline & a & $\mathrm{b}$ & $\mathrm{b}$ & $\mathrm{c}$ & $\mathrm{b}$ & $\mathrm{a}$ & $\mathrm{a}$ & $\mathrm{c}$ & $\mathrm{b}$ & $\mathrm{a}$ & a & $\mathrm{c}$ & $\mathrm{c}$ & $\mathrm{ab}$ \\
\hline \multicolumn{15}{|l|}{ Spruce } \\
\hline Mean & 47 & 0.98 & 0.57 & 55 & 2128 & 33 & 25 & 3.0 & 0.54 & 2.6 & 0.12 & 1.7 & 0.28 & 0.09 \\
\hline \multirow[t]{2}{*}{ SD } & 1 & 0.03 & 0.03 & 1 & 96 & 4 & 8 & 0.2 & 0.09 & 0.1 & 0.01 & 0.1 & 0.01 & 0.01 \\
\hline & $\mathrm{a}$ & $\mathrm{d}$ & $\mathrm{b}$ & $\mathrm{a}$ & $\mathrm{b}$ & $\mathrm{b}$ & $\mathrm{a}$ & $\mathrm{c}$ & $\mathrm{b}$ & $\mathrm{b}$ & $\mathrm{b}$ & $\mathrm{d}$ & $\mathrm{b}$ & $\mathrm{b}$ \\
\hline \multicolumn{15}{|c|}{ Douglas-fir } \\
\hline Mean & 48 & 1.46 & 0.72 & 38 & 1713 & 31 & 25 & 6.4 & 0.83 & 2.4 & 0.09 & 2.7 & 0.54 & 0.15 \\
\hline \multirow[t]{2}{*}{ SD } & 1 & 0.04 & 0.01 & 1 & 22 & 4 & 6 & 0.1 & 0.08 & 0.1 & 0.00 & 0.1 & 0.07 & 0.03 \\
\hline & $\mathrm{a}$ & $\mathrm{a}$ & $\mathrm{a}$ & d & $\mathrm{c}$ & $\mathrm{b}$ & $\mathrm{a}$ & $\mathrm{a}$ & $\mathrm{a}$ & $\mathrm{c}$ & $\mathrm{c}$ & $\mathrm{a}$ & $\mathrm{a}$ & $\mathrm{a}$ \\
\hline$P$ & 0.0022 & $<0.0001$ & $<0.0001$ & $<0.0001$ & $<0.0001$ & 0.0069 & 0.7692 & $<0.0001$ & 0.0016 & $<0.0001$ & $<0.0001$ & $<0.0001$ & $<0.0001$ & 0.0421 \\
\hline
\end{tabular}


Table 2 Elemental composition of forest floor horizons and whole forest floor. $\mathrm{O}^{*}$ is the deepest horizon of the forest floor which is either $\mathrm{Oh}$, Of-Oh or Of-Ah. The values for whole forest floor were calculated using the dry weight of each horizon/sub-horizon as weighting factor (weighted average values - WAV)

\begin{tabular}{|c|c|c|c|c|c|c|c|c|c|c|c|c|c|}
\hline Horizon & Species & $\begin{array}{l}\mathrm{C} \\
\%\end{array}$ & $\begin{array}{l}\mathrm{N} \\
\%\end{array}$ & $\begin{array}{l}\mathrm{P} \\
\% 0\end{array}$ & $\begin{array}{l}\mathrm{C}: \mathrm{N} \\
\text { atomic } \\
\text { ratio }\end{array}$ & $\begin{array}{l}\mathrm{C}: \mathrm{P} \\
\text { atomic } \\
\text { ratio }\end{array}$ & $\begin{array}{l}\mathrm{Ca} \\
\mathrm{g} \mathrm{kg}^{-1}\end{array}$ & $\begin{array}{l}\mathrm{Mg} \\
\mathrm{g} \mathrm{kg}^{-1}\end{array}$ & $\begin{array}{l}\mathrm{K} \\
\mathrm{g} \mathrm{kg}^{-1}\end{array}$ & $\begin{array}{l}\mathrm{Na} \\
\mathrm{g} \mathrm{kg}^{-1}\end{array}$ & $\begin{array}{l}\mathrm{Mn} \\
\mathrm{g} \mathrm{kg}^{-1}\end{array}$ & $\begin{array}{l}\mathrm{Al} \\
\mathrm{g} \mathrm{kg}^{-1}\end{array}$ & $\begin{array}{l}\mathrm{Fe} \\
\mathrm{g} \mathrm{kg}^{-1}\end{array}$ \\
\hline \multicolumn{14}{|l|}{ Oln } \\
\hline & oak & 47 & 1.2 & 0.46 & 44 & 2647 & 5.5 & 1.1 & 2.2 & 0.1 & 3.3 & 1.2 & 0.5 \\
\hline & beech & 50 & 1.6 & 0.71 & 36 & 1791 & 3.1 & 0.5 & 2.7 & 0.1 & 1.5 & 0.6 & 0.3 \\
\hline & spruce & 48 & 1.2 & 0.36 & 48 & 3476 & 3.8 & 0.3 & 1.2 & 0.0 & 1.7 & 0.4 & 0.1 \\
\hline & Douglas-fir & 50 & 1.5 & 0.47 & 38 & 2764 & 5.5 & 0.7 & 1.3 & 0.1 & 2.2 & 0.5 & 0.2 \\
\hline \multicolumn{14}{|l|}{ Olv } \\
\hline & oak & 47 & 1.4 & 0.58 & 38 & 2103 & 4.2 & 0.9 & 2.3 & 0.2 & 2.4 & 2.0 & 0.6 \\
\hline & beech & 47 & 2.2 & 0.83 & 25 & 1465 & 4.0 & 0.6 & 2.3 & 0.3 & 2.0 & 2.0 & 0.6 \\
\hline & spruce & 45 & 1.5 & 0.58 & 35 & 2001 & 4.3 & 0.4 & 1.3 & 0.1 & 1.9 & 1.0 & 0.3 \\
\hline & Douglas-fir & 51 & 2.5 & 0.72 & 24 & 1817 & 5.7 & 0.7 & 1.4 & 0.1 & 2.4 & 1.5 & 0.7 \\
\hline \multicolumn{14}{|l|}{ Of } \\
\hline & oak & 41 & 1.9 & 0.80 & 25 & 1312 & 5.0 & 0.8 & 4.2 & 0.7 & 3.9 & 6.7 & 2.3 \\
\hline & beech & 42 & 2.2 & 0.93 & 22 & 1166 & 4.1 & 0.8 & 4.4 & 1.2 & 2.5 & 11.2 & 3.1 \\
\hline & spruce & 42 & 1.8 & 0.70 & 28 & 1560 & 3.2 & 0.5 & 3.9 & 0.7 & 2.3 & 6.9 & 2.1 \\
\hline & Douglas-fir & 44 & 2.3 & 0.79 & 22 & 1435 & 3.3 & 0.5 & 6.3 & 1.0 & 1.8 & 7.9 & 1.9 \\
\hline \multicolumn{14}{|l|}{$\mathrm{O}^{*}$} \\
\hline & oak & 30 & 1.5 & 0.73 & 23 & 1063 & 2.6 & 1.0 & 12.5 & 2.4 & 2.1 & 24.8 & 6.6 \\
\hline & beech & 21 & 1.0 & 0.62 & 25 & 884 & 1.9 & 1.0 & 18.6 & 4.9 & 0.8 & 36.6 & 8.6 \\
\hline & spruce & 33 & 1.6 & 0.73 & 25 & 1180 & 1.9 & 0.7 & 10.9 & 2.3 & 1.1 & 19.1 & 4.9 \\
\hline & Douglas-fir & 31 & 1.7 & 0.64 & 21 & 1240 & 1.3 & 0.6 & 10.5 & 2.3 & 0.3 & 16.2 & 5.6 \\
\hline \multicolumn{14}{|c|}{ Forest floor WAV } \\
\hline & oak & 37 & 1.6 & 0.67 & 27 & 1435 & 4.0 & 0.9 & 7.2 & 1.3 & 2.9 & 13.1 & 3.7 \\
\hline & beech & 37 & 1.6 & 0.77 & 26 & 1221 & 3.1 & 0.7 & 8.9 & 2.2 & 1.6 & 17.1 & 4.2 \\
\hline & spruce & 41 & 1.5 & 0.57 & 32 & 1875 & 3.1 & 0.5 & 5.0 & 1.0 & 1.8 & 8.2 & 2.2 \\
\hline & Douglas-fir & 42 & 2.1 & 0.66 & 24 & 1628 & 3.5 & 0.6 & 5.9 & 1.0 & 1.5 & 8.2 & 2.7 \\
\hline
\end{tabular}

concentrations, the differences between species were the highest in $\mathrm{Ol}$ horizons.

Weighted average values for whole forest floor (symbolized by the expression $W A V$ in the following text) were calculated using the dry weight of each horizon / subhorizon as weighting factor. The WAV of $\mathrm{C}: \mathrm{N}$ ratio for forest floor were the highest under spruce (32\%) and the lowest under Douglas-fir $(24 \%)$. The WAV of C:P ratio were the lowest under beech (1221) and the highest under spruce (1875). Beech forest floor presented the highest WAV of K, $\mathrm{Na}, \mathrm{Al}$ and $\mathrm{Fe}$ concentrations. Oak forest floor exhibited the highest WAV of $\mathrm{Ca}, \mathrm{Mg}$ and $\mathrm{Mn}$ concentrations.

\subsection{Composition of forest floor leachates}

\subsection{1 pH, C- and N-release}

Douglas-fir leachates strongly decreased in $\mathrm{pH}$ with the horizons (Table 3). Whatever the forest floor, the greatest DOC release was observed in Olv horizon. The WAV of DOC release significantly differed between tree species in the order:
Douglas-fir, $1.83 \% \pm 0.08<$ spruce, $2.72 \%$ \% $\pm 0.09<$ beech, $4.30 \% \pm 0.07<$ oak, $5.96 \% \pm 0.66 ; \mathrm{C}_{\text {DoC }}-\mathrm{mg} \quad \mathrm{C}_{\text {total }}-\mathrm{g}^{-1}$ $(P<0.0001)$. Whatever the forest floor, DON release $\left(\mathrm{N}_{\text {DON }}-\mathrm{mg} \mathrm{N}_{\text {total }} \mathrm{g}^{-1}\right)$ was the highest in Olv horizon leachates, while $\mathrm{NH}_{4}{ }^{+}$release $\left(\mathrm{N}-\mathrm{mg} \mathrm{N} \mathrm{N}_{\text {total- }} \mathrm{g}^{-1}\right)$ peaked in Of except for beech forest floor (Olv) (Table 3).

The contribution of $\mathrm{N}$ forms ( $\mathrm{DON}, \mathrm{NH}_{4}{ }^{+}$or $\mathrm{NO}_{3}{ }^{-}$) to the total dissolved N-release in leachates changed with the horizons; globally, most of the dissolved $\mathrm{N}$ was released as DON in upper horizon leachates and as $\mathrm{NO}_{3}{ }^{-}$in lower horizon leachates (Fig. 1).

The WAV of DON release significantly differed between tree species (Douglas-fir, $0.60 \pm 0.44<$ spruce, $1.99 \pm 0.07<$ beech, $2.97 \pm 0.35<$ oak, $\left.3.75 \pm 0.31 ; \mathrm{N}_{\text {DON }}-\mathrm{mg} \mathrm{N}_{\text {total }} \mathrm{g}^{-1} ; P<0.0001\right)$. The WAV of $\mathrm{NH}_{4}^{+}$release significantly differed between the broadleaf and coniferous species (oak, 3.90 \pm 0.09 ; beech, $3.91 \pm 0.32>$ spruce, $2.25 \pm 0.09$; Douglas-fir, $2.57 \pm 0.37$; $\left.\mathrm{N}-\mathrm{mg} \mathrm{N}_{\text {total }} \mathrm{g}^{-1} ; P<0.0001\right)$. Also, the WAV of $\mathrm{NO}_{3}{ }^{-}$release significantly differed between tree species (Douglas-fir, $3.10 \pm 0.39$; oak, $2.78 \pm 0.16>$ beech, $1.19 \pm 0.11>$ spruce, $0.24 \pm 0.04 ;$ N-mg.N $\left.\mathrm{N}_{\text {total }}-\mathrm{g}^{-1} ; P<0.0001\right)$. 
Table 3 DOC, DON, $\mathrm{NH}_{4}^{+}$and $\mathrm{NO}_{3}^{-}$in forest floor horizon leachates. $\mathrm{O}^{*}$ is the deepest horizon of the forest floor which is either Oh, Of-Oh or Oh-Ah. For each horizon, means with different associated letters are significantly different from one another at the $P<0.05$ level according to the Fisher's least significant difference test $(n=3)$

\begin{tabular}{|c|c|c|c|c|c|c|c|c|c|c|c|c|c|c|c|c|}
\hline \multirow[t]{3}{*}{ Horizon } & \multirow[t]{3}{*}{ Species } & \multicolumn{3}{|l|}{$\mathrm{pH}$} & \multicolumn{3}{|l|}{ DOC } & \multicolumn{3}{|l|}{ DON } & \multicolumn{3}{|l|}{$\mathrm{NH}_{4}^{+}$} & \multicolumn{3}{|l|}{$\mathrm{NO}_{3}^{-}$} \\
\hline & & \multirow[b]{2}{*}{ Mean } & \multirow{2}{*}{\multicolumn{2}{|c|}{$\mathrm{SD}$}} & \multicolumn{3}{|c|}{$\left[\mathrm{C}_{\mathrm{DOC}}-\mathrm{mg} \mathrm{C}_{\text {total }} \mathrm{g}^{-1}\right]$} & \multicolumn{3}{|c|}{$\left[\mathrm{N}_{\mathrm{DON}^{-}}-\mathrm{mg} \mathrm{N}_{\text {total }^{-}} \mathrm{g}^{-1}\right]$} & \multicolumn{3}{|c|}{$\left[\mathrm{N}-\mathrm{mg} \mathrm{N}_{\text {total }}-\mathrm{g}^{-1}\right]$} & \multicolumn{3}{|c|}{$\left[\mathrm{N}-\mathrm{mg} \mathrm{N}_{\text {total }}-\mathrm{g}^{-1}\right]$} \\
\hline & & & & & Mean & SD & & Mean & $\mathrm{SD}$ & & Mean & SD & & Mean & SD & \\
\hline \multirow[t]{5}{*}{ Oln } & oak & 4.0 & 0.0 & $\mathrm{~d}$ & 8.29 & 1.31 & $\mathrm{a}$ & 5.57 & 0.74 & $\mathrm{a}$ & 0.28 & 0.40 & $a b$ & 0.00 & 0.00 & $\mathrm{c}$ \\
\hline & beech & 4.8 & 0.2 & $\mathrm{c}$ & 3.45 & 0.53 & $\mathrm{~b}$ & 2.35 & 0.31 & $\mathrm{~b}$ & 0.09 & 0.04 & $\mathrm{~b}$ & 0.02 & 0.04 & $\mathrm{bc}$ \\
\hline & spruce & 5.3 & 0.1 & $\mathrm{~b}$ & 1.52 & 0.20 & $\mathrm{c}$ & 2.06 & 0.20 & $\mathrm{~b}$ & 0.18 & 0.04 & $\mathrm{~b}$ & 0.08 & 0.01 & $\mathrm{~b}$ \\
\hline & Douglas-fir & 6.1 & 0.1 & $\mathrm{a}$ & 0.78 & 0.04 & $\mathrm{c}$ & 1.60 & 0.03 & $\mathrm{~b}$ & 0.66 & 0.12 & $\mathrm{a}$ & 0.15 & 0.06 & $\mathrm{a}$ \\
\hline & & \multicolumn{4}{|c|}{$P<0.0001$} & \multicolumn{3}{|c|}{$P<0.0001$} & \multicolumn{3}{|c|}{$P<0.0001$} & \multicolumn{2}{|c|}{$P 0.0479$} & & \multicolumn{2}{|c|}{$P 0.0036$} \\
\hline \multirow[t]{5}{*}{ Olv } & oak & 4.4 & 0.1 & $\mathrm{c}$ & 12.12 & 3.58 & $\mathrm{a}$ & 9.81 & 3.16 & $\mathrm{a}$ & 2.44 & 1.74 & $\mathrm{~b}$ & 0.13 & 0.01 & bc \\
\hline & beech & 4.7 & 0.1 & $\mathrm{~b}$ & 8.10 & 0.60 & $\mathrm{~b}$ & 6.12 & 0.56 & $\mathrm{~b}$ & 6.35 & 0.79 & $\mathrm{a}$ & 0.28 & 0.12 & $\mathrm{~b}$ \\
\hline & spruce & 4.5 & 0.0 & $\mathrm{c}$ & 3.09 & 0.07 & $\mathrm{c}$ & 2.63 & 0.17 & $\mathrm{c}$ & 0.52 & 0.09 & $\mathrm{c}$ & 0.03 & 0.04 & $\mathrm{c}$ \\
\hline & Douglas-fir & 5.3 & 0.0 & $\mathrm{a}$ & 2.95 & 0.31 & $\mathrm{c}$ & 2.01 & 0.14 & $\mathrm{c}$ & 2.81 & 0.51 & $\mathrm{~b}$ & 0.90 & 0.20 & $\mathrm{a}$ \\
\hline & & \multicolumn{4}{|c|}{$P<0.0001$} & \multicolumn{3}{|c|}{$P 0.0007$} & \multicolumn{3}{|c|}{$P 0.0026$} & \multicolumn{2}{|c|}{$P 0.0006$} & & \multicolumn{2}{|c|}{$P<0.0001$} \\
\hline \multirow[t]{5}{*}{ Of } & oak & 4.7 & 0.1 & $\mathrm{a}$ & 4.99 & 0.66 & $\mathrm{a}$ & 3.38 & 0.64 & $\mathrm{a}$ & 8.21 & 0.78 & $\mathrm{a}$ & 4.70 & 0.01 & $\mathrm{~b}$ \\
\hline & beech & 4.6 & 0.1 & $\mathrm{ab}$ & 4.84 & 0.37 & $\mathrm{a}$ & 2.77 & 0.42 & $a b$ & 4.82 & 0.63 & $\mathrm{~b}$ & 1.03 & 0.12 & $\mathrm{c}$ \\
\hline & spruce & 4.5 & 0.0 & $\mathrm{~b}$ & 3.89 & 0.53 & $\mathrm{~b}$ & 2.39 & 0.44 & $\mathrm{~b}$ & 3.78 & 0.11 & $\mathrm{~b}$ & 0.35 & 0.00 & $\mathrm{c}$ \\
\hline & Douglas-fir & 4.2 & 0.1 & $\mathrm{c}$ & 2.54 & 0.54 & $\mathrm{c}$ & 1.11 & 0.80 & $\mathrm{c}$ & 5.24 & 1.77 & $\mathrm{~b}$ & 5.97 & 1.13 & $\mathrm{a}$ \\
\hline & & \multicolumn{4}{|c|}{$P<0.0001$} & \multicolumn{3}{|c|}{$P 0.0002$} & \multicolumn{3}{|c|}{$P 0.0087$} & $P 0$. & 038 & & $P<0$. & \\
\hline $\mathrm{O}^{*}$ & oak & 4.4 & 0.1 & $\mathrm{a}$ & 1.04 & 0.15 & $\mathrm{~b}$ & 1.28 & 0.16 & $\mathrm{a}$ & 2.70 & 0.13 & $\mathrm{a}$ & 3.54 & 0.12 & $\mathrm{a}$ \\
\hline & beech & 4.4 & 0.1 & $\mathrm{a}$ & 1.35 & 0.34 & $a b$ & 0.83 & 0.03 & $\mathrm{~b}$ & 2.89 & 0.50 & $\mathrm{a}$ & 3.29 & 0.48 & $\mathrm{a}$ \\
\hline & spruce & 4.4 & 0.0 & $\mathrm{a}$ & 1.65 & 0.15 & $\mathrm{a}$ & 1.02 & 0.14 & $\mathrm{~b}$ & 1.84 & 0.24 & $\mathrm{~b}$ & 0.27 & 0.11 & $\mathrm{~b}$ \\
\hline & Douglas-fir & 3.7 & 0.1 & $\mathrm{~b}$ & 0.27 & 0.07 & $\mathrm{c}$ & 0.38 & 0.07 & $\mathrm{c}$ & 0.09 & 0.04 & $\mathrm{~b}$ & 3.48 & 0.68 & $\mathrm{a}$ \\
\hline & & & $P<0$. & & & & .000 & & & 0001 & & $P<0$. & 001 & & $P<0$ & \\
\hline
\end{tabular}

\subsubsection{Anionic signature}

The contribution of each anion to the total anionic charge widely differed with the horizons (Fig. 2) and between species (Fig. 3). Whatever the tree species, we observed a strong dominance of organic anions in Ol leachates (65-92 $\%)$, except in the leachates of Douglas-fir Olv $(38 \% \pm 10)$. Most of anions was released as $\mathrm{NO}_{3}{ }^{-}$in Of and $\mathrm{O}^{*}$ leachates of oak, beech and Douglas-fir (65-85\%).

In the whole forest floor (WAV) (Fig. 3), $\mathrm{NO}_{3}{ }^{-}$strongly dominated in Douglas-fir leachates $(71 \% \pm 1)$ while it was organic anions in spruce leachates $(62 \% \pm 2)$. In oak and beech leachates, both $\mathrm{NO}_{3}{ }^{-}$and organic anions contributed largely to the anionic charge, but the contribution of $\mathrm{NO}_{3}{ }^{-}$ was larger for oak than for beech $(41 \% \pm 4$ vs $30 \% \pm 3$; $P<0.0001)$.

3.5 $\mathrm{C}$ - and $\mathrm{N}$-mineralization in forest floor horizons and whole forest floors

Whatever the tree species, C-mineralization $\left(\mathrm{C}-\mu \mathrm{g} \mathrm{C}_{\text {total }} \mathrm{g}^{-1}\right.$ $\mathrm{d}^{-1}$ ) strongly decreased from $\mathrm{Ol}$ to $\mathrm{O}^{*}$ (Fig. 4). The WaVof Cmineralization computed for each forest floor (Table 4) was the largest in the oak forest floor $(P<0.0001)$. By contrast, we observed only minor differences of $\mathrm{C}$-mineralization between beech, spruce and Douglas-fir forest floors.

Whatever the tree species, the relative nitrification (\%) increased from Of to $\mathrm{O}^{*}$ (Fig. 5). However, this increase was very low under spruce in comparison with the other species. In Oln, relative nitrification (\%) did not significantly differ between tree species (Table 4). In Olv, Of and $\mathrm{O}^{*}$, the highest values of relative nitrification were observed under Douglas-fir, whereas the lowest values were observed under spruce (Olv, $P=0.1386$; Of, $P<0.0001$; O*, $P<0.0001)$. The $W A V$ of relative nitrification significantly decreased in the following order: Douglas-fir $>$ oak $>$ beech $>$ spruce $(P<0.0001)$.

\section{Discussion}

Litter decomposition is mainly affected by climate, soil and vegetation (Meentemeyer 1978). Here, the four forest tree stands developed in homogeneous conditions of soil and climate (Ranger et al. 2004). The differences of forest floor properties are closely linked with tree species. 

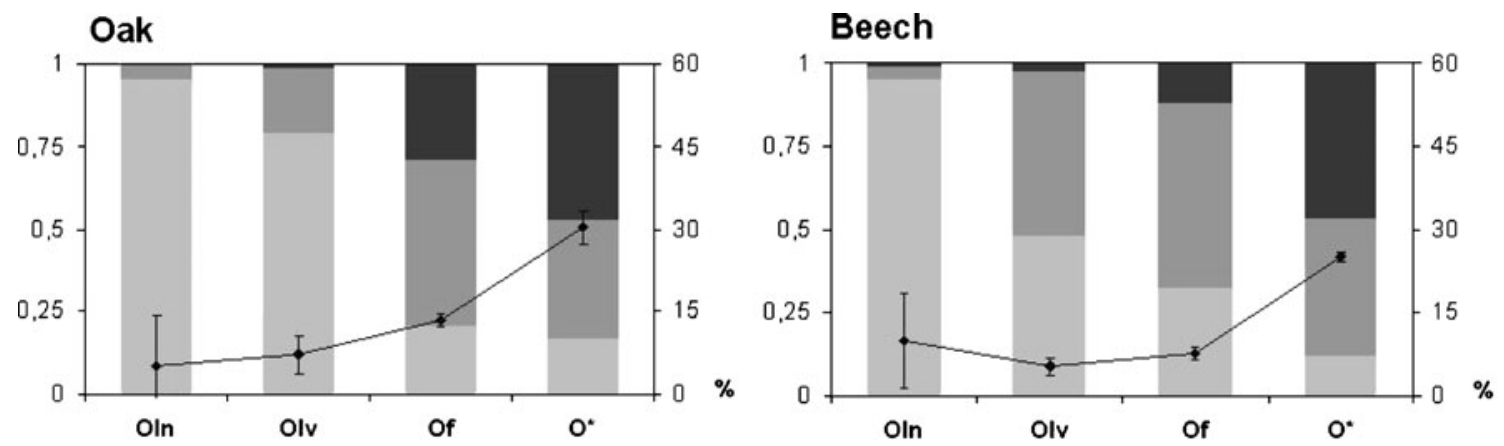

Spruce

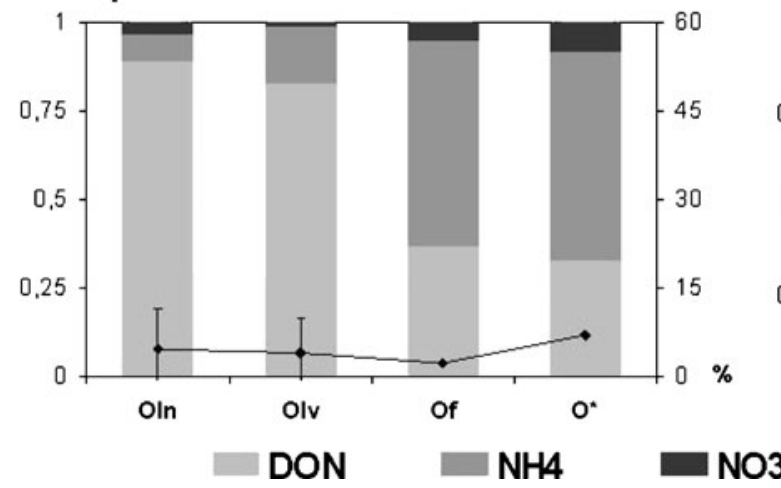

Douglas-fir

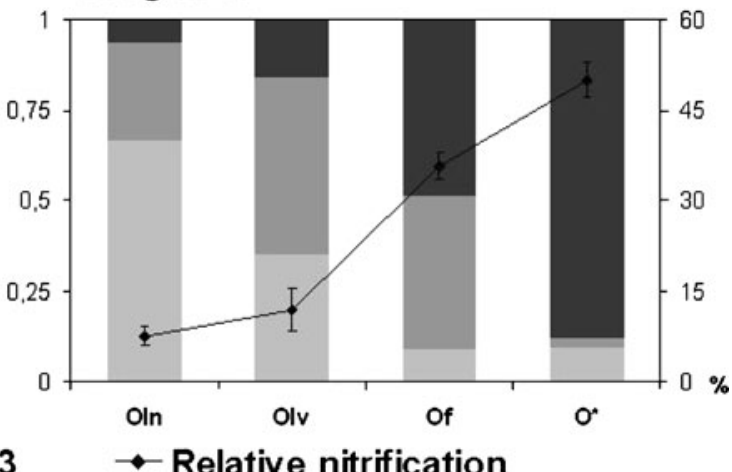

Fig. 1 Proportional contributions of DON, $\mathrm{NH}_{4}{ }^{+}$and $\mathrm{NO}_{3}{ }^{-}$to total $\mathrm{N}$ release in forest floor horizon leachates (left $Y$-axis) and relative nitrification $(\%)$ in forest floor horizons (right $Y$-axis, mean values are reported $\pm \mathrm{SD}$ )

\subsection{Impact of tree species on litterfall quality}

As observed by Alban (1982), litterfall composition is significantly affected by tree species, and might directly affect the composition of the whole forest floor. The concentrations of $\mathrm{K}, \mathrm{Na}$ and $\mathrm{Mg}$ in the forest floor were positively correlated to $\mathrm{K}, \mathrm{Na}$ and $\mathrm{Mg}$ concentrations in litterfall $(r=0.71,0.72$ and 0.69 respectively). There was also a strong correlation
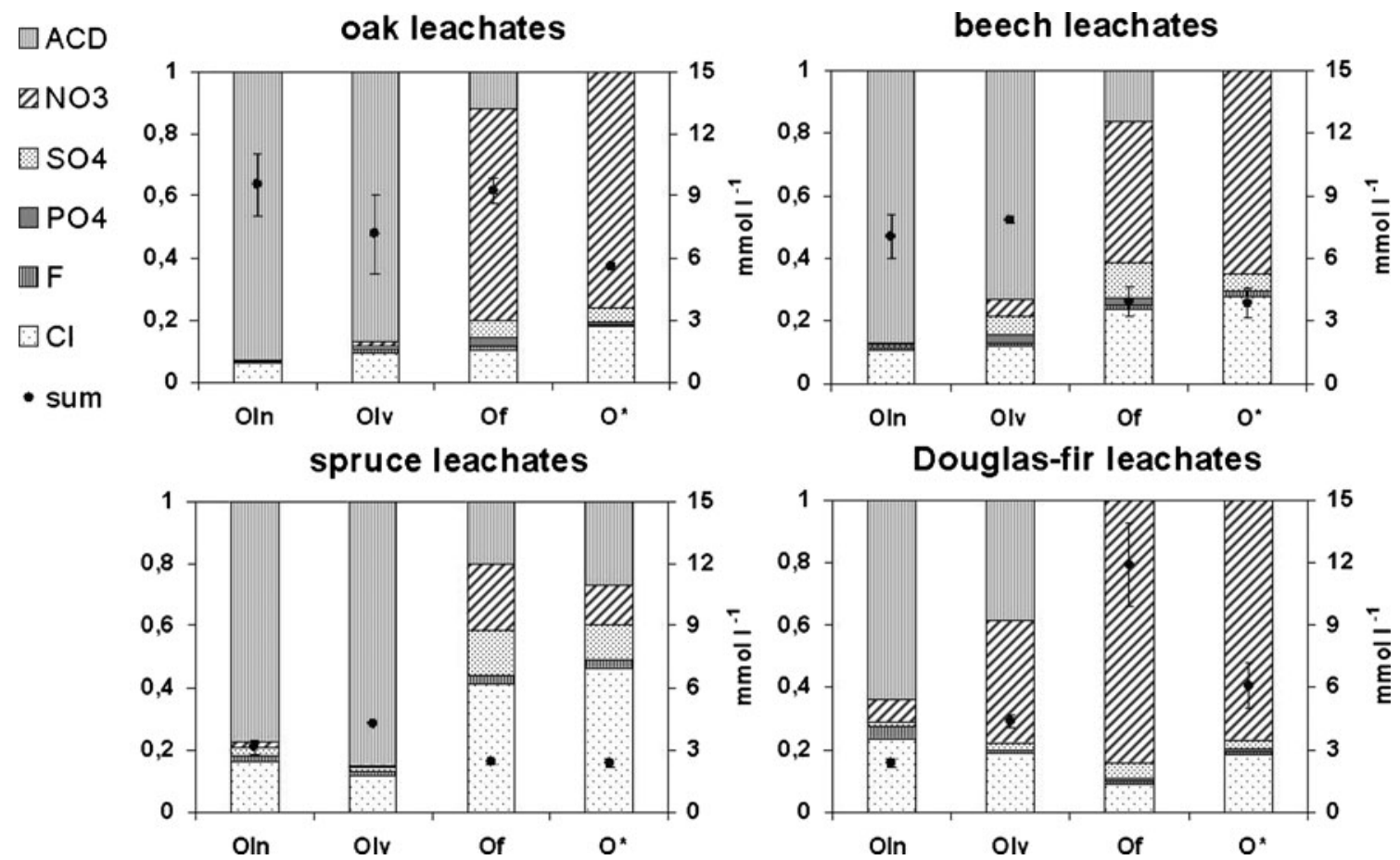

Fig. 2 Proportional contributions of anions $\left(\mathrm{ACD}^{*}, \mathrm{NO}_{3}{ }^{-}, \mathrm{SO}_{4}{ }^{2-}, \mathrm{PO}_{4}{ }^{3-}, \mathrm{F}^{-}\right.$and $\left.\mathrm{Cl}^{-}\right)$in forest floor horizons leachates (left $\mathrm{Y}$-axis) and sum of anions in $\mathrm{mmol}^{-1}$ (right Y-axis, mean values are reported $\pm \mathrm{SD}$ ). $\left(^{*}\right) \mathrm{ACD}$ is the "deficit in anionic charge" 


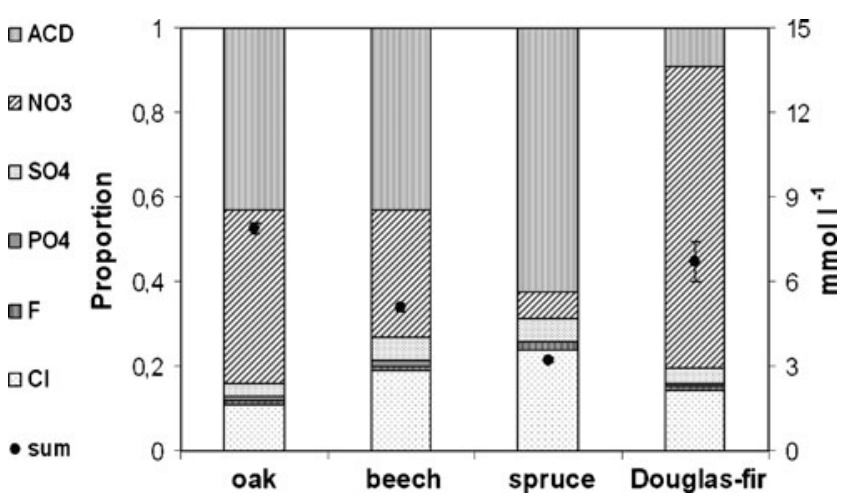

Fig. 3 Proportional contributions of anions (ACD, $\mathrm{NO}_{3}{ }^{-}, \mathrm{SO}_{4}{ }^{2-}$, $\mathrm{PO}_{4}{ }^{3-}, \mathrm{F}^{-}$and $\mathrm{Cl}^{-}$) in the whole forest floors leachates (left Y-axis) and sum of anions in mmol. $1^{-1}$ (right Y-axis, mean values are reported $\pm \mathrm{SD}$ ). The values for the whole forest floor were calculated using the dry weight of each horizon / sub-horizon as weighting factor (weighted average values - $W A V)$

( $r=0.97, P=0.0368, n=4)$ between $\mathrm{C}: \mathrm{N}$ in forest floors and corresponding litterfalls. However, Vesterdal et al. (2008) studied six tree species including all of ours except Douglasfir in a common garden, and found no correlation between $\mathrm{C}$ : $\mathrm{N}$ of forest floors and corresponding litterfalls. The particularly low C:N in Douglas-fir forest floor and litterfall could explain this divergence. Vesterdal and Raulund-Rasmussen (1998) found also C:N ratio in Douglas-fir forest floor significantly lower than in six other tree species forest floors on average on seven sites of different nutrient status.

Vesterdal and Raulund-Rasmussen (1998) concluded that differences in forest floor nutrient status may not only reflect differences in litter nutrient status, and that the initial nutrient status of litter has probably been mediated by variable decomposition rates and nutrient dynamics.

In our study, the concentration of $\mathrm{Ca}, \mathrm{Mn}, \mathrm{Al}$ and $\mathrm{Fe}$ in forest floors were poorly correlated to corresponding concentrations in litterfall. This absence of clear relationship could be attributed to differences between species concerning (i) the loss of these cations from forest floor horizons by leaching and root uptake (Currie et al. 1999), and/or (ii) the relative accumulation of divalent cations and metals as a result of C-loss by mineralization. These cations are strongly bound to humic compounds, as compared to monovalent cations and Mg (Yavitt and Fahey 1984). The evolution of cation concentrations during litter decay should be influenced by the balance between cation- and C-release. If we apply these hypotheses to our data, the higher C-mineralization under oak as compared with other species could partly explain the highest concentrations of $\mathrm{Ca}, \mathrm{Mg}$ and $\mathrm{Mn}$ in oak forest floor. Vesterdal (1998) found also that oak tended to have higher basal respiration rate than the other species. Furthermore, spruce roots preferentially colonize forest floor (Puhe 2003). Root uptake in this forest floor may reduce cation release.

\subsection{Impact of tree species on $\mathrm{C}$ - and $\mathrm{N}$-transformation}

As previously reported, our results support the conclusion that (i) tree species exert a strong control on $\mathrm{C}$ - and $\mathrm{N}$ cycling (Gower and Son 1992; Lovett et al. 2004), particularly on nitrification (Zeller et al. 2007), and (ii) tree species can modify $\mathrm{N}$-cycling rates in a short time (decades) relative to soil development (Gower and Son 1992). In addition, our study shows that the profile pattern of $\mathrm{C}$ - and $\mathrm{N}$-transformation was not impacted by the tree species, and that only the "intensity" of $\mathrm{C}$ - and $\mathrm{N}$ transformation was impacted.

Our results are consistent with previous studies on the same experimental site. The effect of tree species on Cmineralization in forest floors was identical to their effect on $\mathrm{C}$-mineralization in Ah horizon measured by Moukoumi et al. (2006) (spruce $>$ beech $>$ Douglas-fir; oak was not considered in their study). As often reported in the literature, beneath the spruce stand, a very low value of nitrification has been observed both in Ah horizon (Zeller et al. 2007) and in forest floor. It might be attributed to the relatively large $\mathrm{C}: \mathrm{N}$ in litterfall. Nitrification might be affected by roots, either through the competitive absorption of $\mathrm{NH}_{4}^{+}$(Hart et al. 1994) or through the excretion of molecules affecting microorganisms (Turpault et al. 2007). Living roots were not included in our experiments, but the composition of microbial populations may be impacted by contact with roots before sampling.

In our study, the large rates of C-mineralization in oak forest floor, relatively to other tree species, can not be explained by litterfall composition. No correlation was observed between $\mathrm{C}$-mineralization and litter quality indexes such as $\mathrm{C}: \mathrm{N}$, lignin: $\mathrm{N}$ and lignin defined by Melillo and Aber (1982) or such as Mn concentration defined by Berg et al. (2007). This could be primarily attributed to discrepancy in litter decomposition. Such discrepancy could come from absence of allelopathic compounds (Kraus et al. 2003; Lorenz et al. 2004). Kuiters and Denneman (1987) reported that polyphenol concentrations were higher in the forest floor and soil under Norway spruce and beech

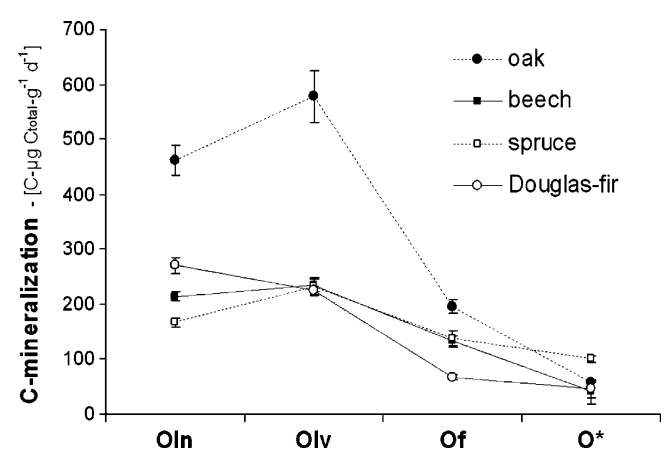

Fig. 4 C-mineralization in forest floor horizons of each species 
Table 4 C-mineralization, net N-nitrification and relative nitrification in forest floor horizons and in the whole forest floor. The relative nitrification (\%) is defined by the ratio between (1) final $\mathrm{NO}_{3}{ }^{-}$in the

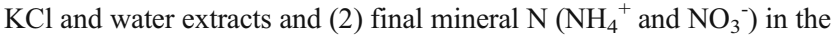
$\mathrm{KCl}$ and water extracts. The values for the whole forest floor were calculated using the dry weight of each horizon/sub-horizon as weighting factor (weighted average values - WAV). For each horizon, means with different associated letters are significantly different from one another at the $P<0.05$ level according to Fisher's least significant difference test $(n=3)$

\begin{tabular}{|c|c|c|c|c|c|c|c|c|c|c|}
\hline \multirow[t]{3}{*}{ Horizon } & \multirow[t]{3}{*}{ Species } & \multicolumn{3}{|c|}{ C-mineralization } & \multicolumn{3}{|c|}{ N-nitrification } & \multicolumn{3}{|c|}{ Relative nitrification } \\
\hline & & \multicolumn{3}{|c|}{$\left[\mathrm{C}-\mu \mathrm{g} \mathrm{C}_{\text {total }} \mathrm{g}^{-1} \mathrm{~d}^{-1}\right]$} & \multicolumn{3}{|c|}{$\left[\mathrm{N}-\mu \mathrm{g} \mathrm{N}_{\text {total }} \mathrm{g}^{-1} \mathrm{~d}^{-1}\right]$} & \multicolumn{3}{|l|}{$\%$} \\
\hline & & Mean & $\mathrm{SD}$ & & Mean & SD & & Mean & SD & \\
\hline \multirow[t]{5}{*}{ Oln } & oak & 462 & 28 & $\mathrm{a}$ & 15 & 26 & $\mathrm{a}$ & 5 & 9 & $\mathrm{a}$ \\
\hline & beech & 214 & 8 & $\mathrm{c}$ & 32 & 28 & a & 10 & 9 & $\mathrm{a}$ \\
\hline & Spruce & 167 & 8 & $\mathrm{~d}$ & 1 & 1 & $\mathrm{a}$ & 5 & 7 & $\mathrm{a}$ \\
\hline & Douglas-fir & 270 & 15 & $\mathrm{~b}$ & 37 & 11 & $\mathrm{a}$ & 7 & 2 & $\mathrm{a}$ \\
\hline & & & & 0001 & & & 1825 & & & $P 0.8006$ \\
\hline \multirow[t]{5}{*}{ Olv } & oak & 578 & 47 & $\mathrm{a}$ & 60 & 5 & $\mathrm{a}$ & 7 & 3 & $a b$ \\
\hline & beech & 234 & 12 & $\mathrm{~b}$ & 35 & 6 & $\mathrm{~b}$ & 5 & 1 & $a b$ \\
\hline & Spruce & 232 & 14 & $\mathrm{~b}$ & 9 & 14 & $\mathrm{c}$ & 4 & 6 & $\mathrm{~b}$ \\
\hline & Douglas-fir & 224 & 7 & $\mathrm{~b}$ & 69 & 8 & $\mathrm{a}$ & 12 & 3 & $\mathrm{a}$ \\
\hline & & & & 0001 & & & 0002 & & & $P 0.1386$ \\
\hline \multirow[t]{5}{*}{ Of } & oak & 196 & 13 & $\mathrm{a}$ & 185 & 31 & $\mathrm{a}$ & 13 & 2 & $\mathrm{~b}$ \\
\hline & beech & 133 & 10 & $\mathrm{~b}$ & 34 & 10 & $\mathrm{c}$ & 8 & 1 & $\mathrm{c}$ \\
\hline & Spruce & 138 & 13 & $\mathrm{~b}$ & 19 & 3 & $\mathrm{c}$ & 2 & 0 & d \\
\hline & Douglas-fir & 67 & 4 & $\mathrm{c}$ & 110 & 26 & $\mathrm{~b}$ & 36 & 2 & $\mathrm{a}$ \\
\hline & & & & 0001 & & & 0001 & & & $P<0.0001$ \\
\hline \multirow[t]{5}{*}{$\mathrm{O}^{*}$} & oak & 57 & 0 & $\mathrm{~b}$ & 122 & 24 & $\mathrm{a}$ & 30 & 3 & $\mathrm{~b}$ \\
\hline & beech & 40 & 21 & $\mathrm{~b}$ & 73 & 21 & $a b$ & 25 & 1 & $\mathrm{c}$ \\
\hline & Spruce & 100 & 5 & $\mathrm{a}$ & 34 & 3 & $\mathrm{~b}$ & 7 & 0 & $d$ \\
\hline & Douglas-fir & 45 & 15 & $\mathrm{~b}$ & 96 & 44 & $\mathrm{a}$ & 50 & 3 & $\mathrm{a}$ \\
\hline & & & & 0021 & & & 0232 & & & $P<0.0001$ \\
\hline \multicolumn{11}{|c|}{ Forest floor (WAV) } \\
\hline & oak & 196 & 9 & $\mathrm{a}$ & 138 & 22 & $\mathrm{a}$ & 19 & 2 & $\mathrm{~b}$ \\
\hline & beech & 130 & 10 & $\mathrm{c}$ & 42 & 4 & $\mathrm{c}$ & 11 & 1 & $\mathrm{c}$ \\
\hline & Spruce & 147 & 3 & $\mathrm{~b}$ & 19 & 3 & $\mathrm{~d}$ & 4 & 1 & d \\
\hline & Douglas-fir & 125 & 6 & $\mathrm{c}$ & 86 & 20 & $\mathrm{~b}$ & 30 & 1 & $\mathrm{a}$ \\
\hline & & & & 0001 & & & .0001 & & & $P<0.0001$ \\
\hline
\end{tabular}

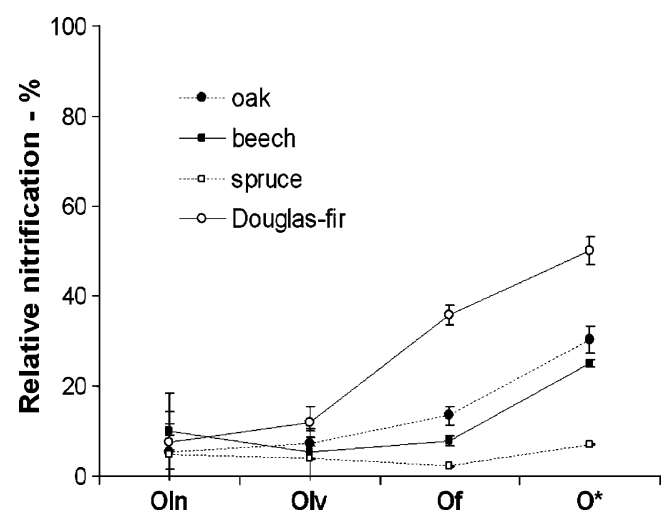

Fig. 5 Relative nitrification in forest floor horizons of each species than under oak. It could also come from difference in micro- and meso-organism populations (Hobbie et al. 2006; Templer et al. 2003) and from different microbial access to organic $\mathrm{N}$ and $\mathrm{P}$ sources, rather than by different total amounts of $\mathrm{N}$ and $\mathrm{P}$ (Vesterdal 1998).

The contribution of $\mathrm{N}$ forms (DON, $\mathrm{NH}_{4}{ }^{+}$and $\mathrm{NO}_{3}{ }^{-}$) in leachates changes according to the forest floor horizons. Our results confirmed the suggestion of Qualls et al. (1991): DON leached from the forest floor originates essentially from the upper forest floor where soluble organic matters are present. In lower horizons, leachates (Of and $\mathrm{O}^{*}$ ), DIN $\left(=\mathrm{NH}_{4}{ }^{+}\right.$and $\mathrm{NO}_{3}{ }^{-}$) dominated, corresponding to larger net ammonification and net nitrification. 


\subsection{Impact of tree species on $\mathrm{C}$ - turnover}

C-stocks in forest floor were smallest under broadleaved species (oak: $9.1 \mathrm{Mg} \mathrm{ha}^{-1} \pm 3.2$; beech: $7.8 \mathrm{Mg} \mathrm{ha}^{-1} \pm 2.6<$ spruce: $21.5 \mathrm{Mg} \mathrm{ha}^{-1} \pm 11.6$; Douglas-fir: $16.4 \mathrm{Mg} \mathrm{ha}^{-1} \pm 4.9$, data from Ranger et al. 2004), although C-input from litterfall was similar whatever the tree species, which probably reveals a faster C-turnover in oak and beech forest floors as compared with coniferous species. This faster C-turnover might be related to (i) the higher $\mathrm{C}$ mineralization in oak forest floor and (ii) the higher DOC releases from both oak and beech forest floors. Our results showed that DOC release must be considered in C-turnover calculation, because it accounted for $22 \%$ (d), $40 \%$ (b), $51 \%$ (c) and $56 \%$ (d) $(P<0.0001)$ of the total C-output $\left(\mathrm{CO}_{2}+\mathrm{DOC}\right)$, under Douglas-fir, spruce, beech and oak respectively. Such large DOC contributions to C-output were also observed in the studies of Qualls et al. (1991) and Yavitt and Fahey (1984), which reported that about 30\% of the annual $\mathrm{C}$-release $\left(\mathrm{CO}_{2}+\mathrm{DOC}\right)$ from a lodgepole pine forest floor was DOC. Fröberg et al. (2007) even observed that DOC loss accounted for $42 \%$ of the total mass loss of a litter of Norway spruce.

4.4 Impact of tree species on the release of aqueous proton donors

The anionic signature widely differed between the four tree species. The strongest contrast was observed between spruce and Douglas-fir, with dominance of $\mathrm{NO}_{3}{ }^{-}$in Douglas-fir leachates, and organic anions in spruce leachates. According to Cronan (1978), the anionic charge deficit (ACD) may be largely attributed to deprotonated organic acids. The higher $\mathrm{NO}_{3}{ }^{-}$contribution in Douglas-fir leachates can be attributed to the larger net nitrification and low DOC release in this forest floor as compared with other species. A high value of relative nitrification in Douglas-fir forest floor may explain the low $\mathrm{pH}$ values in corresponding leachates. Indeed, relative nitrification might be considered as a balance between nitrification and ammonification, which directly affects proton budget in soils, through either proton release or proton consumption (Van Breemen et al. 1983).

The composition of forest floor leachates has direct impact on soil development. Nitric and organic acids induce mineral weathering (Ugolini and Sletten 1991), whereas corresponding anions may contribute to the leaching of cations and metals from topsoil, leading to nutrient depletion, soil acidification and podzolization (Aber 1992; Currie et al. 1999; Van Breemen et al. 1983). Low pH under Douglas-fir and oak may promote mineral weathering, while large DOC concentration under spruce may promote acido-complexolysis (Augusto et al. 1998).

\section{Conclusion}

We conclude that tree species induce a specific signature of proton donors at the forest floor level (organic vs nitric acid) because of their impact on $\mathrm{C}$ - and N-cycling. The release of proton donors can directly impact pedogenetic process in mineral horizons beneath. Consequently, soil degradation could be influenced by setting up of wellchosen tree species stands. However, as root uptake of cations and anions is not considered in our experiment, we cannot draw further conclusions on the effect of root uptake of nutrients on the control of nitrification. We believe that interesting perspectives could involve in situ studies taking into account key processes impacted by tree species: nutrient uptake, root exudation, element leaching from canopy.

Acknowledgements We are sincerely thankful to L. Gelhaye, C. Givron, A. Iserentant, A. Lannoye and P. Populaire for the technical assistance with forest floor sampling and analysis, and to anonymous reviewers for very helpful suggestions on the manuscript.

\section{References}

Aber JD (1992) Nitrogen cycling and nitrogen saturation in temperate forest ecosystems. TREE 7:220-224

AFES (1998) Association Française pour l'Etude du Sol. A sound reference base for soils. INRA, Versailles, France

Alban DH (1982) Effects of nutrient accumulation by aspen, spruce and pine on soil properties. Soil Sci Soc Am J 46:853-861

Augusto L, Bonnaud P, Ranger J (1998) Impact of tree species on forest soil acidification. For Ecol Manage 105:67-78

Berg B, Steffen KT, McClaugherty C (2007) Litter decomposition rate is dependent on litter $\mathrm{Mn}$ concentrations. Biogeochemistry 82:29-39

Binkley D, Giardina C (1998) Why do tree species affect soils? The wrap and the woof of tree-soil interactions. Biogeochemistry 42:89-106

Bonneau M, Brêthes A, Lacaze JF, Lelong F, Levy G, Nys C, Souchier B (1977) Modification de la fertilité des sols sous boisement artificiel de résineux purs. C.R. Fin d'étude D.G.R.S.T., Nancy, Champenoux

Brêthes A, Brun JJ, Jabiol B, Ponge B, Toutain F (1995) Classification of forest humus forms: a French proposal. Ann For Sci 52:535-546

Cronan CS (1978) A soil column tension lysimeter that minimizes experimental edge effects. Soil Sci 125:306-309

Currie WS, Aber JD, Driscoll CT (1999) Leaching of nutrient cations from the forest floor: effects of nitrogen saturation in two longterm manipulations. Can J For Res 29:609-620

Fröberg M, Kleja DB, Hagedorn F (2007) The contribution of fresh litter to dissolved organic carbon leached from a coniferous forest floor. Eur J Soil Sci 58:108-114

Gower ST, Son Y (1992) Differences in soil and leaf litterfall nitrogen dynamics for five forest plantations. Soil Sci Soc Am J 56:1959-1966

Guggenberger G, Kaiser K (1998) Significance of DOM in the translocation of cations and acidity in acid forest soils. Z Planzenernähr Bodenk 161:65-99 
Hansen K, Vesterdal L, Schmidt IK, Gundersen P, Sevel L, Bastrup-Birk A, Pedersen LB, Bille-Hansen J (2009) Litterfall and nutrient return in five tree species in a common garden experiment. For Ecol Manage 257:2133-2144

Hart SC, Nason GE, Myrold DD, Perry DA (1994) Dynamics of gross nitrogen transformations in an old-growth forest: the carbon connection. Ecology 75:880-891

Hobbie SE, Reich PB, Oleksyn J, Ogdahl M, Zytkowiak R, Hale C, Karolewski P (2006) Tree species effect on decomposition and forest floor dynamics in a common garden. Ecology 87:2288-2297

IUSS Working Group WRB (2006) World reference base for soil resources, 2nd ed. World Soil Resources Reports $N^{\circ} 103$. FAO, Rome

Jandl R, Lindner M, Vesterdal L, Bauwens B, Baritz R, Hagedorn F, Johnson DW, Minkkinen K, Byrne KA (2007) How strongly can forest management influence soil carbon sequestration? Geoderma 137:253-268

Kraus TEC, Dahlgren RA, Zasoski J (2003) Tannins in nutrient dynamics of forest ecosystems - a review. Plant Soil 256:41-66

Kuiters AT, Denneman CAJ (1987) Water-soluble phenolic substances in soils under several coniferous and deciduous tree species. Soil Biol Biochem 19:765-769

Lorenz K, Preston CM, Krumrei S, Feger KH (2004) Decomposition of needle/leaf litter from Scot pine, black cherry, common oak and European beech at a conurbation forest site. Can J For Res 123:177-188

Lovett GM, Weathers KC, Arthur MA, Schultz JC (2004) Nitrogen cycling in a northern hardwood forest: do species matter? Biogeochemistry 67:289-308

Meentemeyer V (1978) Macroclimate and lignin control of litter decomposition rates. Ecology 59:465-472

Melillo JM, Aber JD (1982) Nitrogen and lignin control of hardwood leaf litter decomposition dynamics. Ecology 63:621-626

Moukoumi J, Munier-Lamy C, Berthelin J, Ranger J (2006) Effect of tree species substitution on organic matter biodegradability and mineral nutrient availability in a temperate topsoil. Ann For Sci 63:763-771

Puhe J (2003) Growth and development of the root system of Norway spruce (Picea abies) in forest stands - a review. For Ecol Manage 175:253-273

Qualls RG, Haines BL, Swank WT (1991) Fluxes of dissolved organic nutrients and humic substances in a deciduous forest. Ecology $72: 254-266$
Ranger J, Andreux F, Bienaimé S, Berthelin J, Bonnaud P, Boudot JP, Bréchet C, Buée M, Calmet JP, Chaussod R, Gelhaye D, Gelhaye L, Gérard F, Jaffrain J, Lejon D, Le Tacon F, Lévèque F, Maurice JP, Merlet D, Moukoumi J, Munier-Lamy C, Nourisson G, Pollier B, Ranjard L, Simonsson M, Turpault MP, Vairelles D and Zeller B (2004) Effets des substitutions d'essence sur le fonctionnement organo-minéral de l'écosystème forestier, sur les communautés microbiennes et sur la diversité des communautés fongiques mycorhiziennes et saprophytes (cas du dispositif expérimental de Breuil-Morvan). Rapport final du contrat INRA-GIP Ecofor 2001-24 NO. Champenoux, France

Robertson GP (1982) Nitrification in forested ecosystems. Philos Trans R Soc Lond 296:445-457

SAS Institute (1999) SAS/STAT user's guide, version 8 for Windows. SAS Institute, Inc, Cary

Templer P, Findlay S, Lovett GM (2003) Soil microbial biomass and nitrogen transformations among five tree species of the Catskill Mountains, New York, USA. Soil Biol Biochem 35:607-613

Turpault M-P, Gobran GR, Bonnaud P (2007) Temporal variations of rhizosphere and bulk soil chemistry in a Douglas-fir stand. Geoderma 137:490-496

Ugolini F, Sletten RS (1991) The role of proton donors in pedogenesis as revealed by soil solution studies. Soil Sci 151:59-74

Van Breemen N, Mulder J, Driscoll T (1983) Acidification and alkalinisation of soils. Plant Soil 75:283-308

Van Soest PJ (1963) Use of detergent in the analysis of fibrous feeds. II. A rapid method for the determination of fibre and lignin. J Ass Office Anal Chem 46:829-835

Vesterdal L (1998) Potential microbial nitrogen and phosphorus availability in forest floors. Soil Biol Biochem 30:2031-2041

Vesterdal L, Raulund-Rasmussen K (1998) Forest floor chemistry under seven tree species along a soil fertility gradient. Can J For Res 28:1636-1647

Vesterdal L, Schmidt IK, Callesen I, Nilsson LO, Gundersen P (2008) Carbon and nitrogen in forest floor and mineral soil under six common European tree species. For Ecol Manage 255:35-48

Wardle DA (1993) Changes in the microbial and metabolic quotient during leaf litter succession in some New Zealand forest and scrubland ecosystems. Funct Ecol 7:346-355

Yavitt JB, Fahey TJ (1984) An experimental analysis of solution chemistry in a lodgepole pine forest floor. Oikos 43:222-234

Zeller B, Recous S, Kunze M, Moukoumi J, Colin-Belgrand M, Bienaimé S, Ranger J, Dambrinne E (2007) Influence of tree species on gross and net $\mathrm{N}$ transformations in forest soils. Ann For Sci 64:151-158 